\title{
PSYCHE.
}

\section{DIPTERA FROM THE MESILLA VALLEY OF THE RIO GRANDE IN NEW MEXICO. - I.}

BY C. H. TYLER TOWNSEND, LAS CRUCES, NEW MEXICO.

This region has been described, in different papers and at different times, both by Professor Cockerell and myself, so that further description here is unnecessary. For information as to its characteristics, reference may be made to my first and second papers on biogeography of Mexico and the southwestern U. S., in the Transactions of the Texas Academy of Science (18951897).

\section{TABANIDAE.}

I. Tabanus guttatulus Towns.

Syn. Diachlorus guttatulus Towns. Trans. Kans. Acad. Sci, 25th Ann. Meet. pp. I34-5.

Four $9 \mathrm{~s}$ (R. R. Larkin). Las Cruces. Length, $8 \frac{2}{3}$ to $10 \frac{1}{2} \mathrm{~mm}$. This is not a Diachlorus. The portion of front between eyes is about $2 \frac{1}{2}$ times as long as vertical width, the front, therefore, being comparatively wide. The eyes are distinctly pubescent, but the pubescence is not readily noticed. The front tibiae are but little thicker than the others. It probably belongs in
Osten Sacken's section Therioplectes. The above points should be added to my original description. The lateral prolongations of the frontal callosity above are sometimes obsolete, represented only by a brown spot on each side of the small median callosity, which latter may or may not be cut off from the large frontal callosity below it.

SYRPHIDAE.

2. Paragus tibialis var. dimidiatus Lev. Six $\delta \mathrm{s}$. Las Cruces, August 21. On flowers of Aphantostephus arizonicus Gray. Length, 3 to $4 \frac{1}{2} \mathrm{~mm}$. Only a faint shade of brown on tip of abdomen, and all with the second segment more or less broadly red behind. Length of the vertical triangle in one or two of the specimens about twice its greatest width (at posterior corners of eyes), but in the others not over one and one-half times. It thus seems certain that this character will not separate the American from the European forms. See paper on White Sands diptera, for notes on this species. 
3. Nausigaster punctulata Will. One specimen (Ckll.). Rincon, July 5 . On Chilopsis linearis. See section II of paper on Rio Nautla diptera, for notes on separation of species of this genus.

4. Melanostoma stegnum Say. One o (Ckll.). Las Cruces. March 26. On flowers of Prunus (plum).

5. Eupeades volucris OS. Five $q \mathrm{~s}$ (Ckll.). Las Cruces. One, March 2, three March 31, and one April 16, on flowers of Sisymbrium canescens. Length, $6 \frac{1}{2}$ to nearly $9 \mathrm{~mm}$. I have also a $\delta$ (Ckll.) from Roswell, in the Rio Pecos Valley, taken April I4, on flowers of Sisymbrium.

6. Baccha lemur OS. One . . Las Cruces, August Ir. Front and vertex metallic purplish-black, but thorax metallic greenish. Abdomen purplish, of same shade as front.

7. Volucella comstocki Will. Three $\delta \mathrm{s}$, and one $Q$ (Ckll.). Las Cruces. Two ofs, March 23; 9 March 26; one $\delta$ April r. All on flowers of Prunus (plum). Length, ro to I I $\mathrm{mm}$.

\section{CONOPIDAE.}

8. Zodion splendens Jaenn. One $\delta$. Las Cruces, August 21. On flowers of Aphantostephus arizonicus Gray. This specimen measures but little over $6 \mathrm{~mm}$., yet it is without doubt the same species as another $\delta$ (Soledad Cañon, Organ Mts.) which measures I I $\mathrm{mm}$. and is, so far as absolute bulk is concerned, at least five times as large as the present one! The metanotum is shining black in the present specimen, but there is very little black on the pleurae. Scutellum reddish-yellow. Abdomen same color, with the pollen as described by Williston (in $Z$. leucostoma).

\section{GYMNOSOMATIDAE.}

\section{GYMNOSOMA.}

The occurrence in New Mexico of the genus Gymnosoma has never been recorded, and heretofore had not been suspected. During several of the earlier years of my collecting in that region, I never met with a specimen, and I had come to suppose that the New Mexico region was outside of the faunal limits of the genus, due to the general arid character of the country combined with the elevation. Both Gymnosoma and Cistogaster, which two genera form the group Gymnosomatidae, are preëminently inhabitants of the humid lowlands of temperate North America. They occur plentifully along the Atlantic coast slopes, and in the Mississippi Valley and Great Lakes regions. In this respect they resemble the genus Trichopoda, except that the latter is even more highly developed in the tropical lowlands than in the temperate. Trichopoda, besides, is strictly American, and most developed in humid coast regions. It seems absent from subarid coast regions, such as the southern portion of Texas between the Rio Nueces and the Rio Grande-the Costa Deserta of the old Spanish historians. Cistogaster and Gymnosoma are both recorded from portions of humid tropical Amer- 
ica, but they seem to be of far more abundant occurrence in the corresponding temperate portions of North America. Cistogaster has been recorded from Colorado, but probably not from a great elevation.

I was, therefore, much surprised when, in August, i 894, Professor Cockerell showed me a specimen of Gymnosoma which he had just taken at Las Cruces. Several other specimens have been taken in the Mesilla Valley at intervals since; and I secured one in the Sacramento Mts., during a week's collecting there in October, 1896 . The Mesilla Valley specimens are noticed in detail below. At best the genus is of rare or infrequent occurrence in New Mexico.

9. Gymnosoma fuliginosa Desv. Three $\delta \mathrm{s}$ and three $q \mathrm{~s}$. Las Cruces. One $q$ (Ckll.), August 24, on flowers of Solidago canadensis. One \& (Wooton), October 4 , on flowers of Bigelovia wrightii. Óne $q$ (Ckll.), March 23, and one $\delta$ (Ckll.) March 26, both on flowers of Prunus domesticus (plum). One $\delta$ (Ckll.), Sept. I2, on flowers of Bigelovia wrightii. One $\delta$ (C. Rhodes), Sept.

The Sept. I $2 \delta$ measures only $5 \frac{1}{2}$ mm., being considerably smaller than the others, and resembles somewhat $G$. filiola Lw., which was originally described from Texas. I am convinced, however, that it is only a small specimen of fuliginosa. Loew defined filiola as distinguished by its shorter antennae, and it probably must be considered only as a variety of fuliginosa.
The present specimen is considerably larger than Loew's measurement, which is 2 lines. The abdominal spots are very small.

Of the other normal-sized specimens, none has the abdominal spots at all enlarged. In one of the $q \mathrm{~s}$, these spots are very small indeed, while in another they are subobsolete. The $q \mathrm{~s}$ measure $6 \frac{1}{2}$ to $7 \mathrm{~mm}$; the $\delta \mathrm{s}, 6 \frac{1}{2}$ to $6 \frac{2}{3} \mathrm{~mm}$.

Both sexes of this species have the humeri and pleurae silvery pollinose. The scutellum is silvery on apex, and slightly so in middle at base. The $q$ is distinguished by rest of thoracic dorsum being shining black. I pointed out the sexual differences, in the Proc. Ent. Soc. Wash. (vol. II, I89I, p. I4I), where I stated that the thoracic dorsum of $q$ is wholly black shining, but neglected to add that the humeri are silvery.

The specimen above mentioned from the Sacramento Mts. (a $\delta$, Rio Tularosa, Oct. 2, on flowers of Bigelovia graveolens var. glabrata) was taken at an elevation of about $6200 \mathrm{ft}$. This is, doubtless, the greatest elevation at which any specimen of Gymnosoma has ever been taken. The Sacramento Mts. are very humid, far more so than the Mesilla Valley, but at the same time they are much higher. The other specimens, taken at Las Cruces, are from an elevation of about $3800 \mathrm{ft}$. The difference is thus $2400 \mathrm{ft}$.

OCYPTERIDAE.

Io. Ocyptera euchenor Walk. A 
surprising find, made by Prof. Cockerell during the summer of $\mathrm{I} 897$, is a specimen of this species, taken in the Mesilla Valley, on Bigelovia wrightii, August 5. It is the first specimen of the genus ever taken in New Mexico, to my knowledge.

TACHINIDAE s. str.

II. Jurinia lateralis Mcq. Two os (Ckll.), Las Cruces, May 3 and June 9. The former is an undersized specimen, with the abdomen less red on sides.

I2. Gonia sequex Will. Two specimens (Ckll.), Las Cruces. One April 9, on flowers of Prunus domesticus (plum); the other, May 5 .

\section{A NEW ANT-NEST COCCID.}

BY GEO. B. KING, LAWRENCE, MASS., AND J. D. TINSLEY, MESILlA PARK, N. MEX.

The species described below was collected by Mr. King. The notes on the microscopical characters were prepared by Mr. King, but have been extended and rewritten from $\mathrm{Mr}$. King's mounts by Prof. Tinsley, who is also responsible for the comparison with allied species. The drawings are by $\mathrm{Mr}$. Tinsley. The notes on the living insect, and habits, etc., are by Mr. King.

Dactylopius claviger, $\mathrm{n} . \mathrm{sp} .-$ Adult $q$. Length 2.5-3.5 mm. Width about $2 \mathrm{~mm}$. Shape, ovoidal, quite plump. Color, dark reddish-brown, covered with white mealy secretion. Segmentation of body distinct, under hand lens. No lateral or caudal appendages. Boiled in caustic potash it colors the liquid a light violet red. Legs and antennae pale yellowish-brown. Antennae 8-jointed ; 8 longest, longer than $6+7$, and with several whorls of hairs, the hairs being numerous at the distal end ; I next longest, its diameter equalling or slightly exceeding its length, a whorl of hairs around its distal end; 2 next, its diameter about $\frac{3}{4}$ of its length, two whorls of hairs, one about midway and the other near distal end; 5 next, with two whorls of hairs, one at each end ; 7 next, with a whorl of hairs about its middle, 3 next ( 3 and 7 are often subequal), its diameter being about $\frac{2}{3}$ of that of 2 , a whorl of hairs about its middle; 4 and 6 about subequal and with a whorl of hairs about the middle. The joint between 4 and 5 is often, almost usually, quite indistinct, and this might be considered a prominent characteristic. Antennal formula 812573 (46). See figure of antenna. Legs, -

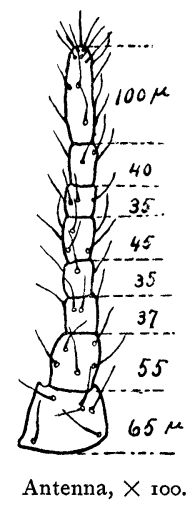

Femur stout being a little over twice as long as wide, quite hairy; tibia, width about $\frac{1}{2}$ the width of the femur, length about equal 

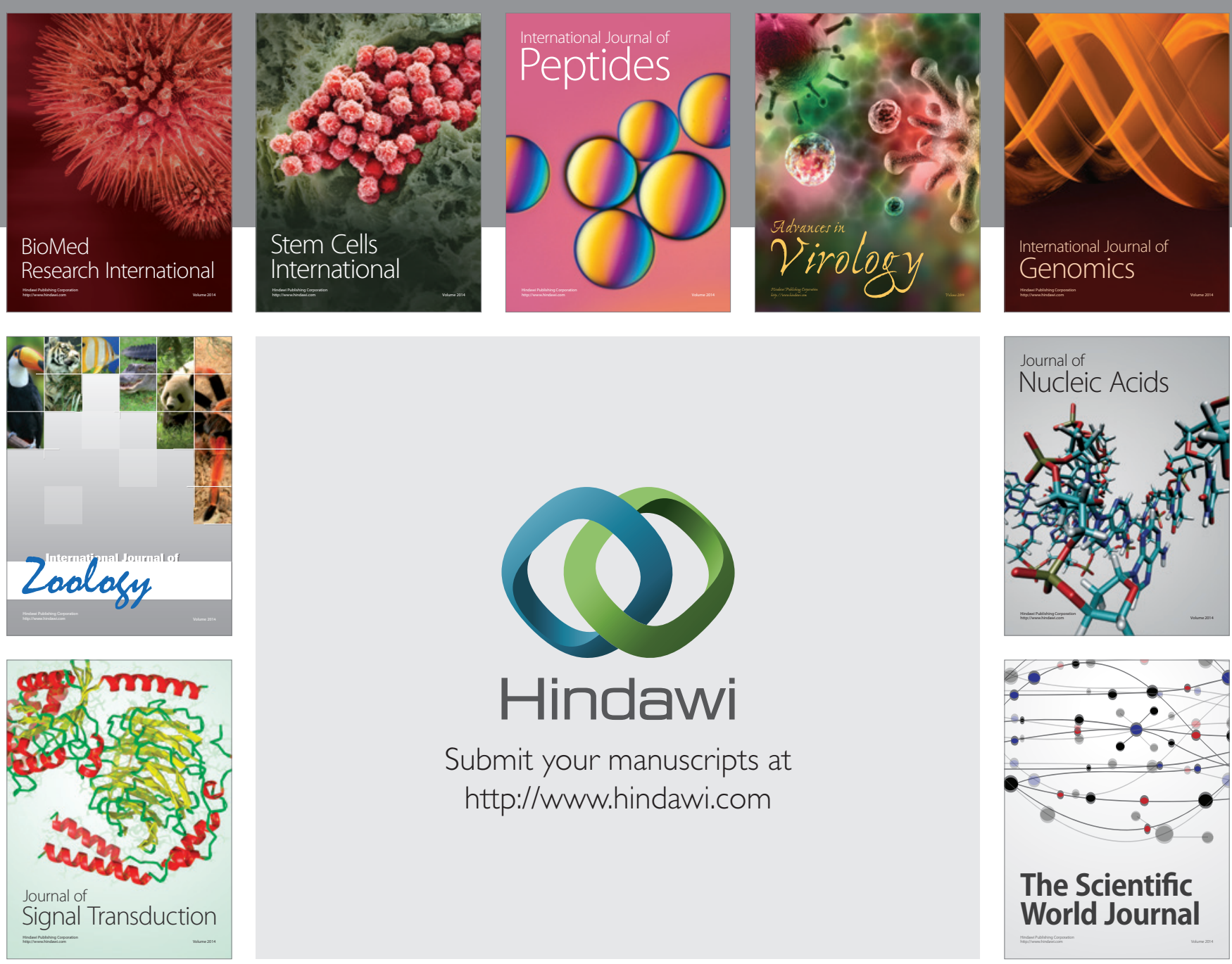

Submit your manuscripts at

http://www.hindawi.com
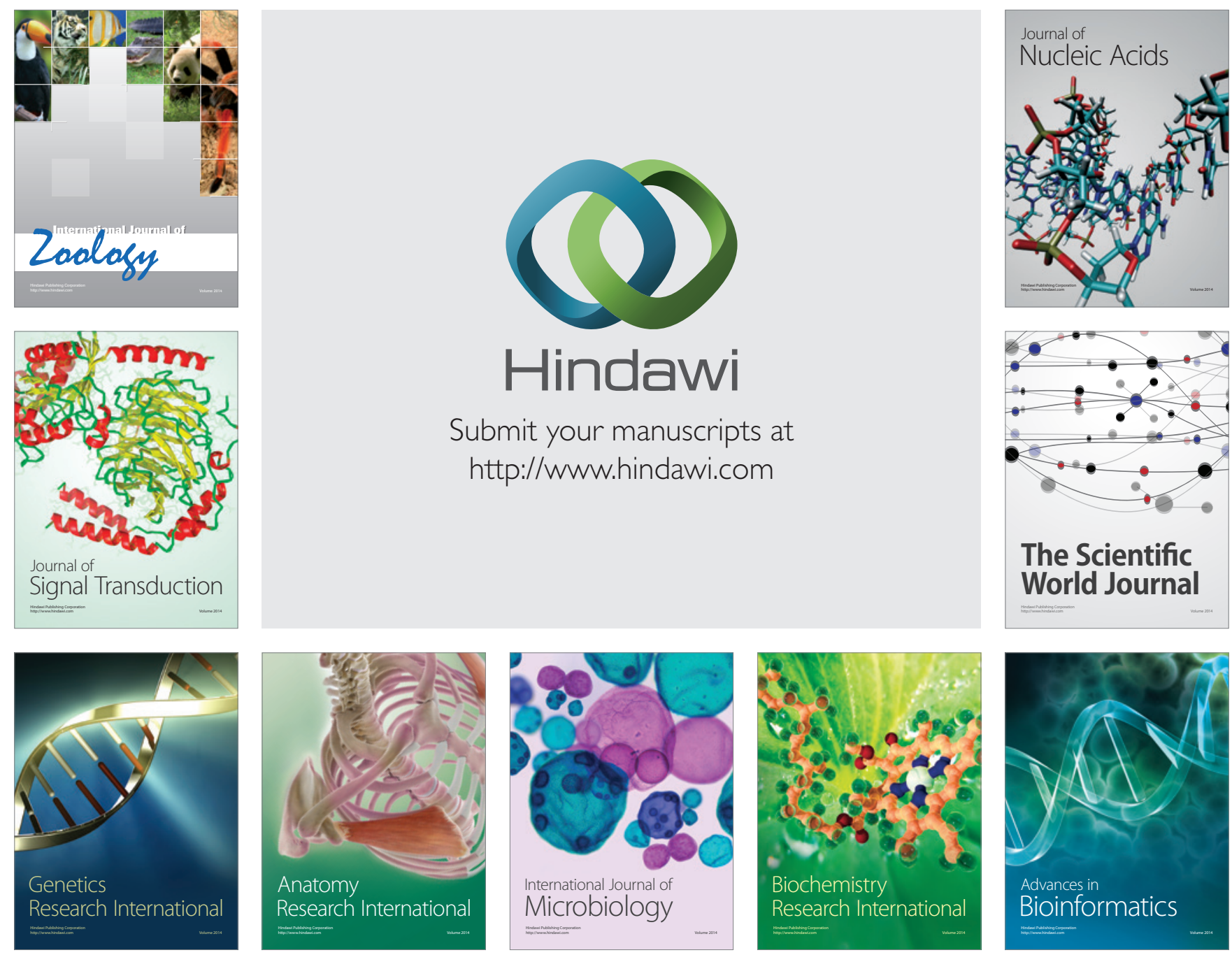

The Scientific World Journal
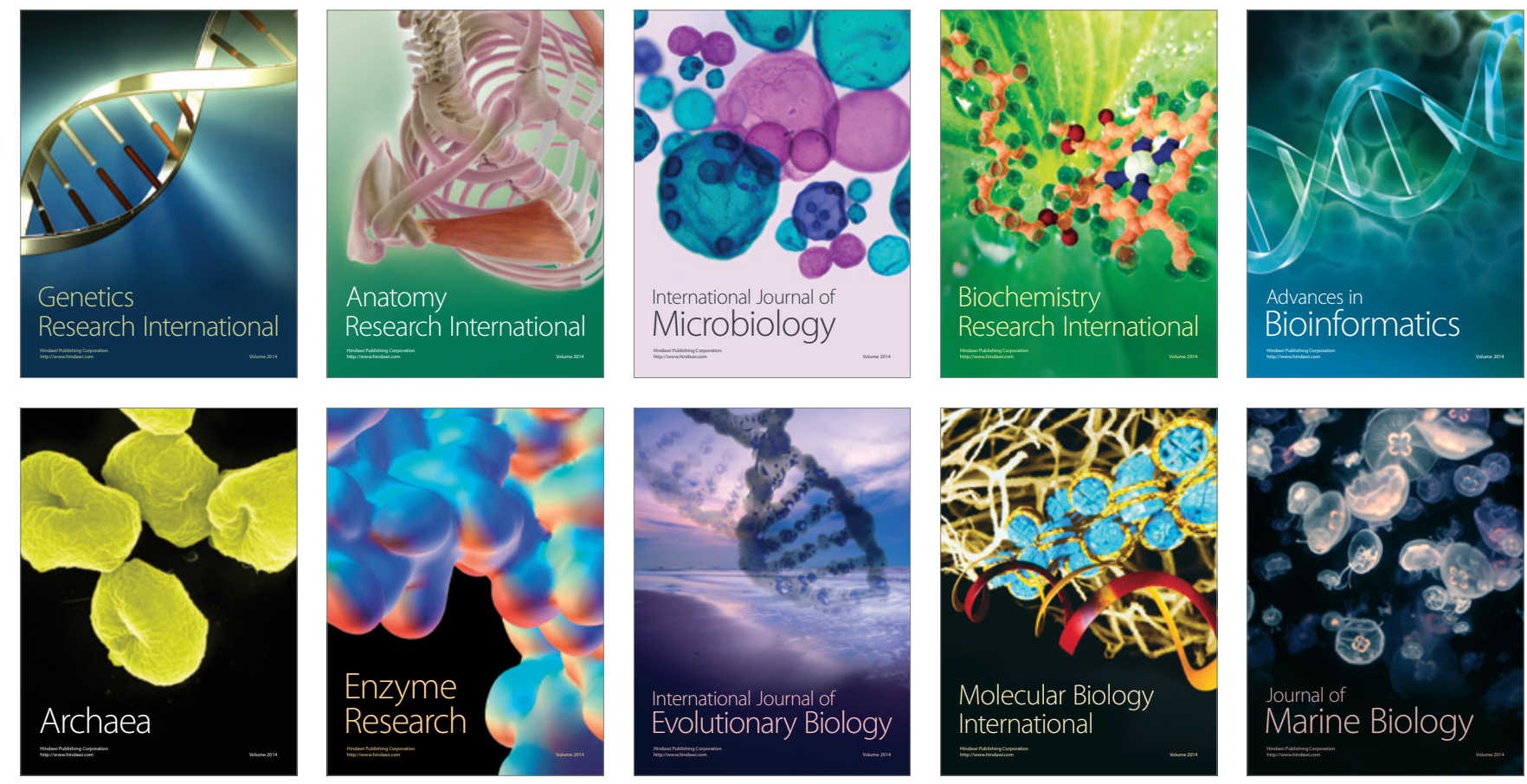